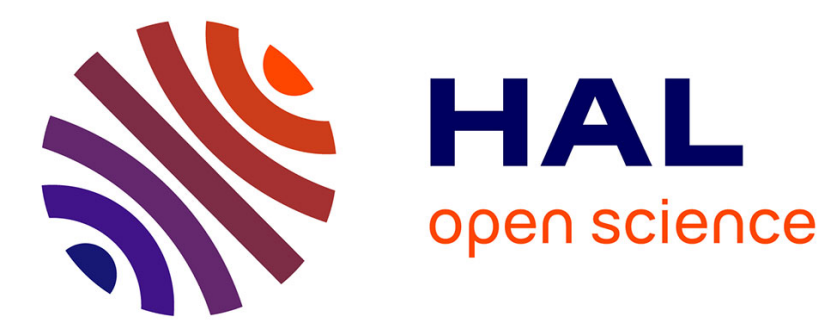

\title{
FRACTURE TOUGHNESS OF SILICA AEROGELS
}

\author{
J. Phalippou, T. Woignier, R. Rogier
}

\section{To cite this version:}

J. Phalippou, T. Woignier, R. Rogier. FRACTURE TOUGHNESS OF SILICA AEROGELS. Journal de Physique Colloques, 1989, 50 (C4), pp.C4-191-C4-196. 10.1051/jphyscol:1989431 . jpa-00229507

\section{HAL Id: jpa-00229507 https://hal.science/jpa-00229507}

Submitted on 1 Jan 1989

HAL is a multi-disciplinary open access archive for the deposit and dissemination of scientific research documents, whether they are published or not. The documents may come from teaching and research institutions in France or abroad, or from public or private research centers.
L'archive ouverte pluridisciplinaire HAL, est destinée au dépôt et à la diffusion de documents scientifiques de niveau recherche, publiés ou non, émanant des établissements d'enseignement et de recherche français ou étrangers, des laboratoires publics ou privés. 
REVUE DE PHYSIQUE APPLIQUEE

Colloque C4, Supplément au $n^{\circ} 4$, Tome 24, avril 1989

\title{
FRACTURE TOUGHNESS OF SILICA AEROGELS
}

\author{
J. PHALIPPOU, T. WOIGNIER and R. ROGIER
}

Laboratoire de Science des Matériaux Vitreux, Université des Sciences et Techniques du Languedoc, F-34060 Montpellier Cedex 02, France

Résumé - Des aérogels de silice ont été élaborés selon les formes adéquates pour réaliser des mesures de ténacité en fonction de la densité. La ténacité des aérogels est mesurée par la méthode SENB en flexion 3 points. KIC varie entre 0,8 et $4,8 \mathrm{KPa} \mathrm{m} \mathrm{m}^{1 / 2}$. Pour les aérogels dont 7 a densité est comprise entre 0,1 et $0,35,1^{\prime}$ analyse des résultats obtenus suggère que KIC varie comme $\rho^{1.6 \pm 0.2}$. Nous présentons la variation de l'énergie de fracture et de la taille du défaut critique tels qu'ils sont calculés à partir des valeurs de la résistance à la rupture et du module d'Young.

Abstract - Silica aerogels of desired shape have been elaborated to perform critical stress intensity factors evaluations as a function of the density. The fracture toughness of aerogels is measured using SENB technique in three-point bending. KIC varies in the range 0.8 to $4.8 \mathrm{KPa} . \mathrm{m}^{1 / 2}$. For aerogels whose bulk density ranges between 0.1 and $0.35 \mathrm{~g} / \mathrm{cm}^{3}$ the analysis of the obtained results suggests that $K_{I C}$ varies as $\rho^{1.6 \pm 0.2}$. The fracture energy variation and the critical size flaw derived from toughness, strength and Young's modulus are also presented and discussed.

\section{I - INTRODUCTION}

The studies of mechanical behaviour of glasses and ceramics are mainly performed on materials close to theoretical density. However other classes of very low density materials are of interest. The last applications concern materials that are to be used in space. The weight of these materials is a very important parameter. The best example of these materials is probably the tiles used on the American space shuttle /1-2/.

Up to now ultralight materials were classified into two families : Materials constituted by entangled fibers and cellular materials constituted by open or closed cells. In any case and whatever is the required application (phonic, thermal insulation) the materials must possess mechanical properties adapted to their function.

Several studies are devoted to these kinds of materials. Models have been proposed to take account of their mechanical properties and then to optimize them.

In the ceramic area, expanded alumina $/ 3 /$, foam-glasses $/ 4-5-6 /$ and entangled fibers materials /1-2/ were up to now the only materials used to realize low density bodies.

Recently a new class of very porous materials has been synthesized. These materials are very interesting because they are light-weight and they show good thermal insulation properties. Depending on synthes is parameters they may be transparent in the frequency range corresponding to visible. These materials are issued from sol-gel process and are called aerogels. We reported here the fracture toughness of silica aerogels.

\section{2 - EXPERIMENTAL}

The synthesis of monolithic silica aerogels was reported previously /7/. In the present work the gels have been synthesized into parallelepipedic shaped "Pyrex" glass containers. The dimensions of the samples are $20 \times 10 \times 110 \mathrm{~mm}^{3}$. The gels are aged and undergo the syneresis phenomenon. After that treatment gels do not stick to the walls container. Then gels are taken to undergo the autoclave treatment. The shrinkage of the alcogels is low and depends on various chemical parameters (content of tetramethoxysilane, solvent...) and on the performed treatments (time and temperature of aging, autoclaving process). Consequently, aerogels have slightly different dimensions depending on their composition.

A series of samples with different densities was elaborated. The figure 1 shows a sample having dimension analogous to that of studied aerogels. However it should be noted that for improving the picture this aerogel was elaborated under basic conditions to increase its transparency $/ 8 /$. 


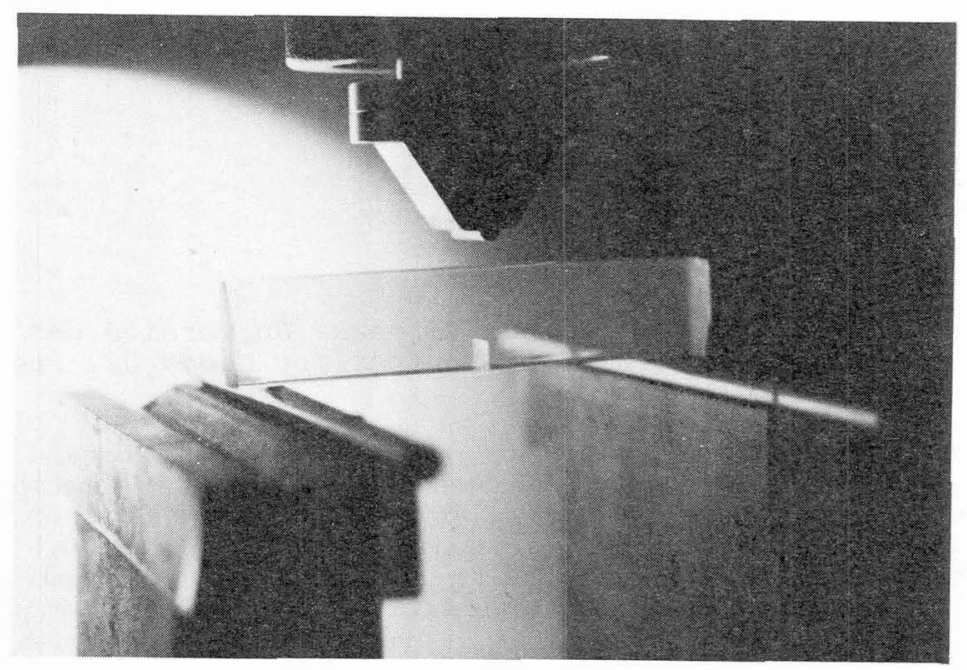

Fig. 1 - Transparent silica aerogel observed just before the SENB test.

The fracture toughness of aerogels was measured using the single edge notched beam (SENB) technique in 3 point bending. Other attempts to elaborate samples in configuration allowing $K$ constant toughness measurements were unsuccessful because to their extreme fragility; for porous materials these last geometries should bring more reliable results $/ 9 \%$.

The saw cut notch was performed using a diamond saw of $50 \mu \mathrm{m}$ width. The notch depth $C$ has a length in such a way that the ratio $C / W$ (systematically optically measured) lies between 0.25 and $0.3 ; W$ is the height of the sample $(\approx 18 \mathrm{~mm}) . W / 1$ is chosen very close to $1 / 4$ ( 1 is the span). With this geometry the value of KIC is given by the relation :

$$
\text { KIC }=\frac{3 P .1}{2 W^{2} \cdot d} \cdot \sqrt{C} \cdot Y
$$

$P$ is the load necessary to break the specimen, $d$ is the width and $Y$ is a polynomial expression depending on the $W / 1$ value $/ 10 /$. In this case :

$$
Y=1.93-3.07 \frac{C}{W}+14.53\left|\frac{C}{W}\right|^{2}-25.11\left|\frac{C}{W}\right|^{3}+25.8\left|\frac{C}{W}\right|^{4} \quad-2-
$$

With this procedure and particularly for porous materials the value of KIc depends on the loading rate. High speed permits to eliminate the low growth flaw process. However these effects are mainly due to the stress corrosion of the material by the atmospheric water at the flaw tip. It was demonstrated that the corrosion is related to the polar nature of the reacting molecule but also to the size of the molecule /11/. An other explanation for the slow fracture propagation has been offered : the change of the fracture rate on KI scale may be due to change in surface energy associated with adsorbed species onto the lips of the flaw $/ 12$. In our material this phenomenon can induce great effects due to the large specific surface area of aerogels (higher than $400 \mathrm{~m}^{2} / \mathrm{g}$ ). However aerogels are hydrophobic and may be less sensible to the water corrosion.

The measurements were performed on a traction-compression machine with a special loading cell allowing to evaluate forces down to $10^{-2} \mathrm{~N}$. The cross head speed is of $10 \mathrm{~cm} / \mathrm{min}$. All the stress-strain curves remain perfectly inear up to the rupture which occurs suddenty.

The apparent density of samples was measured by a simple weight of specimens whose volume is well defined. 


\section{3 - RESULTS AND DISCUSSION}

The figure 2 shows the obtained values for various samples. The reported values are two orders of magnitude lesser than those measured on dense silica glass /13/. The measurements carried out on samples of identical densities, elaborated under strictly identical conditions and treated together show a good reproducibility. The discrepancy is about $0.4 \mathrm{KPa} . \mathrm{m}^{1 / 2}$ irrespective of the sample density. It must be noted that the Brown and Srawley criterion /14/ defining the conditions of plane deformation in front of the crack tip is perfectly respected.

$$
c>2.5\left|\frac{\mathrm{K}_{\mathrm{IC}}}{\mathrm{S}_{\mathrm{Y}}}\right|^{2}
$$

$S_{\gamma}$ is the yield strength and is commonly assumed to be equal to the rupture stress.

Moreover a right measurement of KIC implies that the notch root radius (optically measured) must be lower than a critical value ac $/ 15 /$.

$$
a_{C}=\frac{4}{\pi}\left|\frac{K_{I C}}{S}\right|^{2}
$$

ac is the size of the region ahead of the root of the notch called the "process zone" in which stresses are reduced by microcracking. On an other hand ac must be small compared to other geometric parameters such as the thickness and length of the macroscopic notch. S value have been previously determined /16-17/.

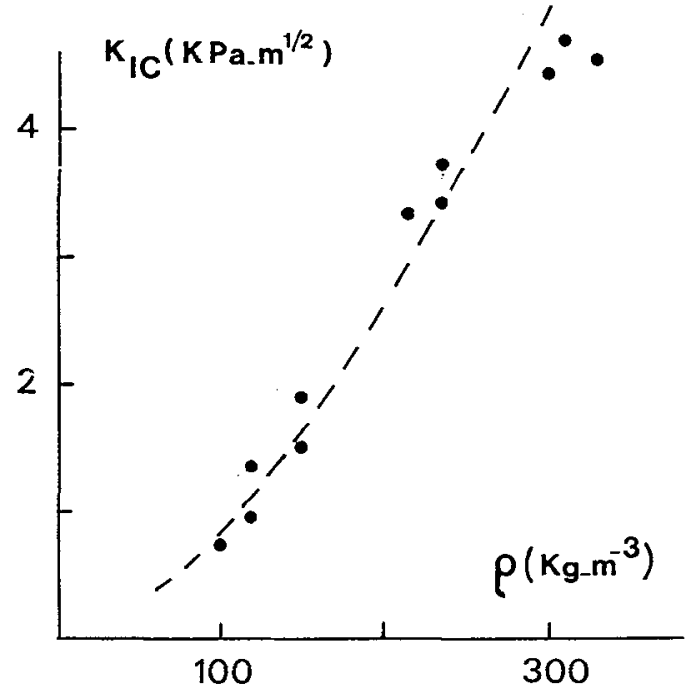

Fig. 2 - Evolution of KIC as a function of density.

For all the studied aerogels these criteria are respected and we may consider the KIC measurements as valid.

Elasticity and strength of highly porous solids have been the focus of numerous experimental and theoretical studies. There are very few models trying to describe the toughness evolution as a function of density.

Some attempts have been successfully applied to tiles or foam-glasses. These models take into account the length of the cell and the thickness of the beams or rods constituting the solid part of the material. They assume that several cells are to be broken to create a critical flaw. 
Maiti et al. /18/ use a quite modified procedure to evaluate the Kic value of porous materials. The crack growth establishes under discrete fashion, every step corresponding to a cell length. The crack can grow by tension fracture of elements situated in front of the fracture. However bending of cell edges may be the process which controls the fracture.

With these assumptions Maiti et al. show that :

$$
K_{I C}=C_{1} \text { Sf } \sqrt{\pi} \ell\left(\frac{\rho}{\rho_{\mathrm{S}}}\right)^{3 / 2}
$$

$C_{1}$ is a constant whose the value is close to 0.65 . Sf is the tension strength of the matter constituting the cell and $\ell$ is the mean cell length. The analysis of our results on a loglog scale (Fig. 3) shows that KIC varies as $\rho^{1.6 \pm 0.2}$.

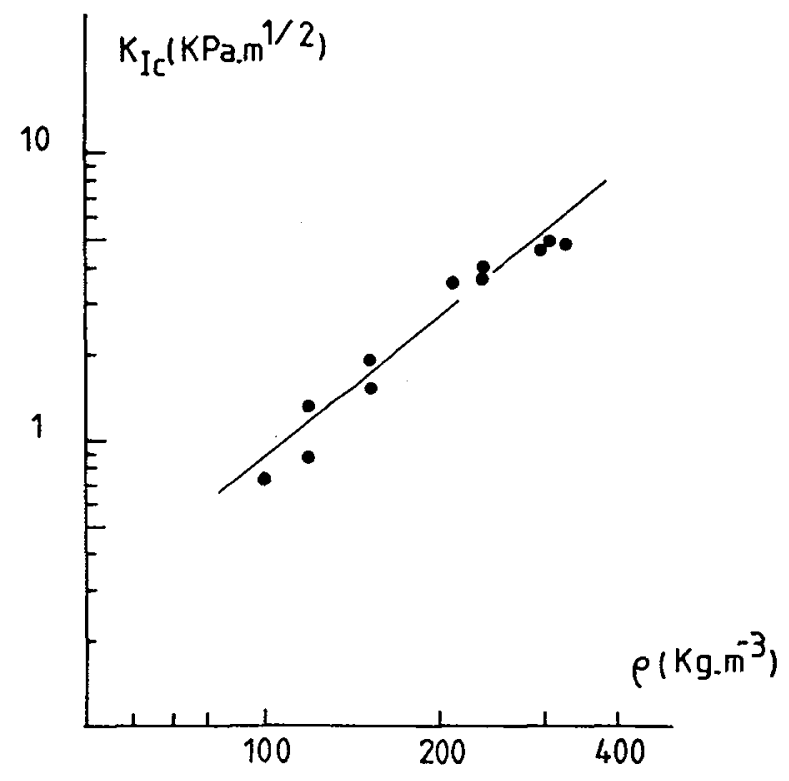

Fig. 3 - Plot of Kic versus density on a log-log scale.

In a first approximation and if we assume that the cell length of aerogels is approximatively constant Maiti's relation seems to account for the obtained results.

We have to keep in mind that the assumption is very crude. In fact we are not able to describe the geometrical shape of the pores of aerogels. Moreover Maiti's model assumes that $E$ varies as $\rho^{2}$. This assumption is not verified for our measurements which show that $E$ varies as $\rho^{3} .7 \pm 0.2$. relation :

The knowledge of $E$ and $\nu$ allows the fracture energy to be evaluated using the

$$
\mathrm{KIC}^{2}=\mathrm{GE} /\left(1-\nu^{2}\right)
$$

where $\nu$ is the Poisson ratio. G, the critical value of the strain energy release rate, is usually related to the initiating fracture energy $\left(\gamma_{i}\right)$ by :

$G=2 \gamma_{i}$

The values of the initiating fracture energy are calculated using $\nu=0.2 / 17 /$ and are much lower than that measured on silica glass. This result must be correlated to the decrease in the total area of the new surfaces generated by the propagating crack.

Similar results have been observed on various porous ceramic materials $/ 20,21 /$. The slope of the curve $\gamma$ vs density on a log-log scale is close to -0.5 . This is a straight forward consequence of the scaling laws observed on $E$ and Kic respectively. 
This behaviour is unexpected with respect to the porosity evolution. It could be the signature of the roughness of the sample. It has been shown on crystals that polycrystalline fracture energies are typically three to tenfold times single crystal fracture energies $122 /$. This result is to a certain extent attributed to the roughness of polycrystaline fracture surface compared to that of single crystal. Very light aerogels $(\rho \simeq 0$.1) develop a real specific surface area (well higher than that measured by B.E.T. technique) much more important than the heaviest.

To account for these results, other hypotheses may be proposed. Oue to the highly reactivity of aerogels the toughness of the gels may be dependent on some plastic work at the crack tip or due to the heat consumed by a chemical reaction. In this material both surface and internal silanols are present in the linked particles which constitute the solid part of the gel $/ 23 /$. These silanol groups under the stress can probably react with the chemical surrounding species affecting the initiation fracture energy.

This surprising behavior of $\gamma$ shows clearly that other experiments are necessary to understand the evolution of fracture energy of these highly porous materials. The size of the critical flaw $\rho_{c}$ is related to the fracture strengths and the KIc by the relationship :

$$
\rho_{C}=\left|\frac{Z}{Y} \frac{K_{I C}}{S}\right|^{2}
$$

$\rho c$ is the critical size of the flaw responsible for the failure, $Y$ is a geometrical parameter depending on the test /14/ and $Z$ is known as a flaw shape parameter /20/.

The main problem concerns the nature of the critical flaw. If we assume that the flaws are similar to Griffith flaws (like in silica glass) $Z=1$ and we find that $\rho_{c}$ varies between 10 and $100 \mu \mathrm{m}$ depending on density. These values are close to that of the flaw found in silica glass $(50 \mu \mathrm{m})$. However with respect to the structure of the aerogel which is built by a fractal spacial arrangement of particles of $10 \AA$ radius, we must assume that these flaws are traversing a large number of particles and pores. On another hand pores can also be considered as the critical flaws or as stress concentrators /24/. In this case $Z$ is not determined for a $30 \mathrm{flaw}$ and it is no longer possible to estimate the critical size of the flaw responsible for the failure of aerogels.

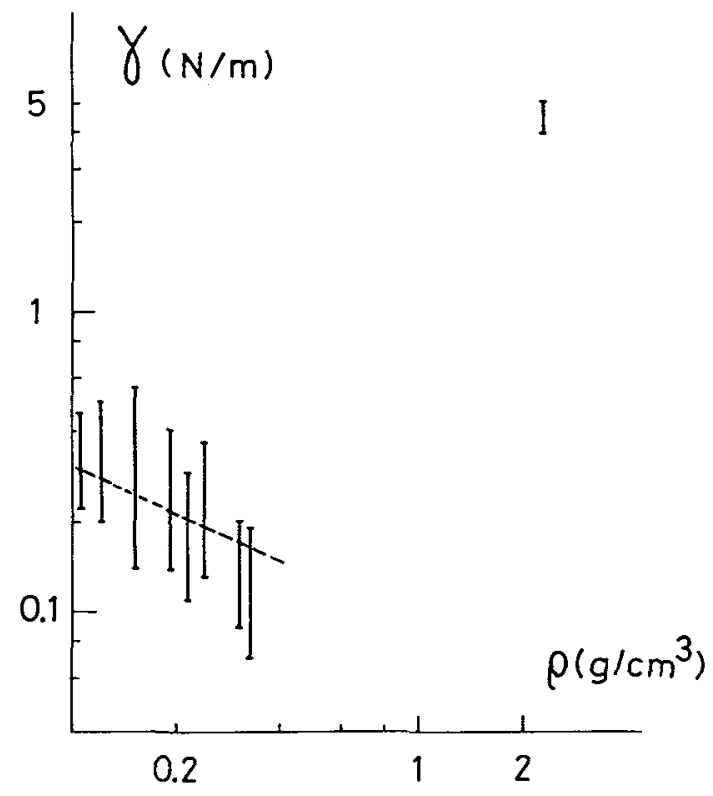

Fig. 4 - Evolution of fracture surface energy as a function of density. 


\section{4 - CONCLUSION}

The fracture toughness of aerogels varies as a function of their densities as $p^{1.6 \pm 0.2}$. This evolution cannot be explained with previously proposed mathematical model because their Young's moduli vary as $\rho^{3.7 \pm 0.2}$. Even if the critical stress intensity factor increases with $\rho$, the evolution of the initiating fracture surface energy decreases. Thus a straighforward relation between $G$ and $\gamma_{i}$ is likely too crude and an additional term ( $\gamma^{\prime}$ ) must be included on the right member of equation 8 which would account for energy release coming from some chemical phenomena probably depending on the sample density. The chemical reactions are due to the chemical nature of the aerogels. Silanol groups, organic groups, siloxane bonds are present in the structure of aerogels. Other experiments are in progress to understand the role played by each of these chemical groups.

\section{REFERENCES}

/1/ GREEN, D.J., "Fracture mechanics of ceramics" 8, Ed. R.C. BRADT, D.P.H. HASSELMAN, F.F. LANGE, Plenum Press, N.Y., (1986) 39.

12/ GREEN, D.J., "Industrial materials and engineering", Ed. L.E. MURR, M. Dekker, N.Y., (1984) 123.

13/ HAGIWARA, H., GREEN, D.J., J. Amer. Ceram. Soc., 70(11) (1987) 811.

/4/ CONLEY, P.H., CHANDAN, H.C., BRADT, R.C., "Fracture mechanics of ceramics", $\frac{4}{7}$, Ed. BRADT, R.C., HASSELMAN, D.P.H., LANGE, F.F., Plenum Press, N.Y. (1978) 761.

/5/ MORGAN, J.S., WOOD, J.L., BRADT, R.C., Materials Science and Engineering, 47 (1981) 37.

/6/ ZWISSLER, J.G., ADAMS, M.A., "Fracture mechanics of ceramics", $\underline{6}$ Ed. R.C. BRADT, D.P.H. HASSELMAN, F.F. LANGE, PTenum Press, N.Y. (1983) 211.

17) PRASSAS, M., PHALIPPOU, J., ZARZYCKI, J., J. Mat. Science, 19 (1984) 1656.

/8/ FRICKE, J., CAPS, R., BÜTTNER, D., HEINEMANN, U., HÜMMER, E., J. Non-Cryst. Solids, 95-96 (1987) 1167 .

19/ EVANS, A.G., "Fracture mechanics of ceramics", 2 Ed. BRADT, R.C., HASSELMAN, D.P.H., LANGE, F.F., Plenum Press, N.Y. (1974) 17.

/10/ A.S.T.M. Special Technical Publication, $n^{\circ} 410$ (1967).

/11/ MICHALSKE, T.A., FREIMAN, S.W., J. Amer. Ceram. Soc., 66 (1983) 284.

/12/ MAUGIS, D., J. Mater. Science, 20 (1985) 3041.

/13/ WIEDERHORN, S.M., J. Am. Ceram. Soc., $\underline{52}$ (1969) 99.

/14/ BROWN, W.F., SRAWLEY, J.E., Am. Soc. Mater., Spec. Tech. Pub1, , 410 (1967) 1.

115/ BURESH, F.E., "Fracture mechanics applied to brittle solids", ASTM-STP 678, ed. FREIMAN, S.W., (1979) 151.

/16/ WOIGNIER, T., PHALIPPOU, J., J. Non-Cryst. Solids, 93 (1987) 17.

/17/ WOIGNIER, T., PHALIPPOU, J., same issue.

/18/ MAITI, S.K., ASHBY, M.F., GIBSON, L.J., Scripta. Metạ1., 18 (1984) 213.

/19/ WOIGNIER, T., PHALIPPOU, J., SEMPERE, R., PELOUS, J., J. Phys. France, 49 (1988) 289.

/20/ EVANS, A.G., TAPPIN, G., Proc. Br. Ceram. Soc. 1972, 20 (1972) 275.

/21/ Simpson, L.A., J. Amer. Ceram. Soc., 56(1) (1973) 7.

/22/ WIEDERHORN, S.M., Mater. Sci. Res., 3 (1966) 503.

/23/ WOIGNIER, T., PHALIPPOU, J., Riv. Della Staz. Speri. Vetro, $\underline{5}$ (1984) 47.

/24/ RICE, R.W., "Treatise on materials science and technology", Vol. II, R.K. MacCrone ed., Acad. Press, (1977) 199. 